\author{
Marek MiŁawicki OP \\ (D) https://orcid.org/0000-0001-9718-6216 \\ DominikańsKi Instytut HistoryCZnY w KRAKOWIE
}

\title{
ŹRÓDŁA DO DZIEJÓW KOŚCIOŁA ORMIAŃSKOKATOLICKIEGO W GALICJI W ZBIORACH WIEDEŃSKICH ${ }^{1}$
}

W marcu 2019 roku miałem okazję przeprowadzać kwerendę w archiwach i bibliotekach wiedeńskich. Miejscem moich poszukiwań było przede wszystkim Austriackie Archiwum Państwowe (Österreichisches Staatsarchiv, dalej: ÖSA) ${ }^{2}$. Większość przejrzanych materiałów źródłowych dotyczyła klasztorów i zakonników dominikańskich z terenów Galicji ${ }^{3}$ Natrafiłem jednak także na dokumenty dotyczące dziejów archidiecezji lwowskiej obrządku ormiańskokatolickiego, która swym zasięgiem obejmowała całą Galicję4.

${ }^{1}$ Artykuł powstał dzięki grantowi nr 11 H 12016981 (Słownik biograficzny zakonów mendykanckich $w$ Polsce w średniowieczu, 1, Dominikanie), finansowanemu przez Narodowy Program Rozwoju Humanistyki.

2 Przebadałem dwa oddziały Österreichisches Staatsarchiv: Ogólne Archiwum Administracji (Allgemeines Verwaltungsarchiv, skrót: AVA) i Archiwum Domu, Dworu i Państwa (Haus-, Hof- und Staatsarchiv, skrót: HHSA).

3 Znajdujące się w ÖSA materiały do historii dominikanów galicyjskich w okresie zaborów planuję omówić w oddzielnym opracowaniu.

${ }^{4}$ O Kościele ormiańskokatolickim w Galicji w okresie zaborów zob.: Z. Obertyński, Kościót ormiański w zaborze austriackim, w: Historia Kościoła w Polsce, 2/1, red. B. Ku mor, Z. Obertyński, Poznań 1979, s. 651-656; R. A. Mark, Galizien unter österreichischer Herrschaft. Verwaltung - Kirche - Bevölkerung, Marburg 1994, Historische und Landeskundliche Ostmitteleuropa - Studien, 13, s. 41-43; G. Petrowicz, La Chiesa armena in Polonia e nei paesi limitrofi, 3, Roma 1988, Studia Ecclesiastica, 17, Historica, 10, s. 189-376. Bardzo ogólnie o Kościele ormiańskokatolickim w monarchii habsburskiej w badanym okresie pisze także W. Bihl, Die Armenischen Kirchen, w: Die Habsburgermonarchie 1848-1918, 4, Die Konfessionen, red. A. Wandruszka, P. Urbanitsch, Wien 1985, s. 479-481. 
W polskiej literaturze naukowej znajdujemy wcale liczne odwołania do zasobów ÖSA, a ponadto omówienia znajdujących się tam poloników ${ }^{5}$, w tym źródeł do dziejów Kościoła katolickiego w Galicji ${ }^{6}$. Z obu tych oddziałów korzystali obficie historycy Kościoła - Bolesław Kumor, na przykład w rozprawie poświęconej ustrojowi i organizacji Kościoła katolickiego pod zaborami ${ }^{7}$, i Jerzy Krętosz, w pracy traktującej o archidiecezji lwowskiej obrządku łacińskiego w okresie józefińskim ${ }^{8}$.

W HHSA 9 szczególnie cenne są dwa zespoły, mianowicie „Diplomatie und Außenpolitik" do 1848 roku i z lat 1848-1918. Oba dotyczą polityki zagranicznej monarchii habsburskiej. Pierwszy zawiera między innymi materiały po Kancela-

5 Zob. na przykład: K. Tyszkowski, Polonica w zbiorach Archiwum Państwowego w Wiedniu (sprawozdanie z poszukiwań archiwalnych głównie dla czasów Zygmunta III), „Archeion”, 5, 1929, s. 70-88; J. Chlebowczyk, Polonica $w$ archiwach wiedeńskich, „Kwartalnik Historyczny", 65, 1958, 1, s. 332-335; J. Woliński, Z. Wójcik, Źródła do historii Polski w Haus-, Hof- und Staatsarchiv w Wiedniu, „Archeion”, 28, 1958, s. 131-157; K. Maleczyński, B. Turoń, Średniowieczne silesiaca i polonica $w$ zbiorach bibliotecznych $i$ archiwalnych w Wiedniu, „Śląski Kwartalnik Historyczny Sobótka”, 18, 1963, 1, s. 84-93; S. Ciara, Kwerenda $w$ archiwach wiedeńskich, „Archeion”, 95, 1995, s. 248-253; J. Krajewska, Polen - Österreich vom 16. bis zum 20. Jahrhundert. Ein Dokumentenführer, Warszawa 1995 (rec.: S. Ciara, „Archeion”, 98, 1997, s. 207-210); Polonika w Austriackim Archiwum Państwowym 1772-1918, oprac. J. Gaul, Warszawa 2003; J. Gaul, Polonika w Allgemeines Verwaltungsarchiv $w$ Wiedniu, „Archeion”, 101, 2000, s. 115-128; idem, Polonika $w$ archiwach austriackich, „Archeion”, 110, 2007/2008, s. 118-144; idem, Polonika w Archiwum Parlamentu w Wiedniu. Archiwum Izby Postów Rady Państwa 1861-1918, Warszawa 2014; idem, Polonika w zespole ,, Urzad Nadzoru Wojennego” w Archiwum Wojny w Wiedniu, „Miscellanea Historico-Archivistica", 24, 2017, s. 311-323.

${ }^{6}$ B. Kumor, Kwerenda naukowa $w$ Haus-, Hof- und Staatsarchiv oraz w Allgemeines Verwaltungsarchiv $w$ Wiedniu w latach 1966-1971, „Summarium”, 3, 1974, 112-115; idem, Ważniejsze polonika kościelne $w$ archiwach państwowych $w$ Wiedniu, „Archiwa, Biblioteki i Muzea Kościelne", 37, 1978, s. 307-311; S. Nabyw aniec, Ecclesiastica galicyjskie w zbiorach Allgemeines Verwaltungsarchiv w Wiedniu, „Prace Historyczno-Archiwalne”, 13, 2003, s. 199-206; A. Pobóg-Lenartowicz, Źródła do dziejów klasztorów śląskich przechowywane w Austriackim Archiwum Państwowym w Wiedniu (Österrichisches Staatsarchiv), ,Śląski Kwartalnik Historyczny Sobótka”, 66, 2011, 4, s. 93-97; G. Ploch, Zespót nr 102, „Klöster und Stifte: Galizien", w Allgemeines Verwaltungsarchiv oraz wybrane inne archiwalia dotyczace klasztorów i zakonów w Galicji w zbiorach Österreichisches Staatsarchiv, w: Kasaty klasztorów na obszarze dawnej Rzeczypospolitej Obojga Narodów i na Ślasku na tle procesów sekularyzacyjnych w Europie, 3, red. M. Derwich, Wrocław 2014, s. 17-45.

7 B. Kumor, Ustrój i organizacja Kościoła polskiego w okresie niewoli narodowej 1772 1918, Kraków 1980.

8 J. Krętosz, Archidiecezja lwowska obrządku łacińskiego w okresie józefinizmu (17721815), Katowice 1996.

9 Szerzej o tym archiwum zob.: L. Gross, Reichsarchive, w: Inventare Österreichischer Staatlicher Archive, 5, Inventare des Wiener Haus-, Hof-und Staatsarchivs; 4, Gesamtinventar des Wiener Haus-, Hof- und Staatsarchiv. Aufgebaut auf der Geschichte des Archivs und seiner Bestände, red. L. Bittner, Wien 1936, s. 273-394. Zob. także: E. Weinzier1, Das 
rii Państwowej (Staatskanzlei, dalej: SK). W tej grupie znajdują się dokumenty wytworzone przez Kancelarię Stanu lub do niej kierowane, w tym korespondencja z rządami poszczególnych prowincji, a więc również z władzami Galicji z lat 1781-1863. Wśród nich zwraca uwagę korespondencja Kancelarii z nuncjuszem apostolskim w Wiedniu w sprawie ormiańskiego kolegium prowadzonego przez teatynów we Lwowie ${ }^{10}$ oraz zabudowań klasztoru i kolegium po ich kasacie w $1784 \mathrm{roku}^{11}$. Dokumentacja tych spraw, wraz z materiałami dotyczącymi seminarium duchownego we Lwowie z lat 1783-1829, znajduje się w jednym kartonie. Znawca dziejów Kościoła katolickiego w Galicji w okresie zaborów ks. Władysław Chotkowski tak o tych źródłach pisał: „Korespondencja w tej sprawie [tj. sprzedaży gmachów poteatyńskich] ze Stolicą Ap[ostolską] ciągnęła się do r. 1829, dla tego że z nią łączyła się nie tylko kwestia pieniędzy za sprzedaż (Kausfschilling) klasztoru Teatynów, ale i seminarium grecko-ormiańskiego i seminarium łacińskiego. Urosła też do kilkunastu fascykułów, któreśmy odszukali w archiwum państwa w Wiedniu i na innym miejscu obszernie o niej powiemy"12.

Należy wspomnieć jeszcze o piśmie z 17 października 1823 roku, w którym cesarz Franciszek I informował gubernatora Galicji Ludwiga von Taaffego o podziale majątku należącego niegdyś do teatynów lwowskich ${ }^{13}$. Do ostatniego z wymienionych źródeł nie dotarłem, informacje o nim podaję na podstawie katalogu archiwum wiedeńskiego dostępnego online na archiwalnym portalu internetowym.

W drugim ze wspomnianych zespołów źródła do dziejów Kościoła ormiańskokatolickiego w Galicji znajdują się w podzespole „Gesandtschafts- und

Haus-, Hof- und Staatsarchiv und die Geschichtswissenchaft 1848-1967, „Mitteilungen des Österreichischen Staatsarchivs", 16, 1963, s. 250-260.

10 ÖSA: HHSA, SK, Provinzen Galizien, 3.2, Korrespondenz der Staatskanzlei mit dem päpstlichen Nuntius betreffend das griechische und armenische Kollegium und das päpstliche Kollegium zu Lemberg, 1816-1829. Szerzej o teatynach lwowskich i ich kolegium zob.: D. Blažejovskyj, Ukrainian and Armenian Pontifical Seminaries of Lviv (1665-1784), Rome 1975; idem, I teatini e i Pontifici Collegi Armeno e Ucraino di Leopoli (1665-1784), „Regnum Dei”, 35, 1979, 105, s. 205-248; J. Kowalczyk, Gmach kolegium Teatynów we Lwowie i jego twórcy - Salvi i Chiaveri, w: Sztuka Kresów Wschodnich, 5, red. A. Betlej, P. Krasny, Kraków 2003, s. 53-64; G. Scarabelli, I teatini a Leopoli, „Regnum Dei”, 59, 2003, 129, s. 211-223.

11 ÖSA: HHSA, SK, Provinzen Galizien, 3.3, Korrespondenz der Staatskanzlei mit dem päpstlichen Nuntius und der vereinigten Hofkanzlei betreffend die Verwendung des aus dem Verkaufe des Theatiner Klostergebäudes zu Lemberg gelösten Kulturschillings, 1783-1829.

12 W. Chotkowski, Historya polityczna dawnych klasztorów panieńskich w Galicyi 1773-1848 na podstawie akt Cesarskiej Kancelaryi Nadwornej, Kraków 1905, s. 72. Wydaje się, że zapowiedziany artykuł nie powstał.

13 ÖSA: HHSA, SK, FA Taaffe, 39-39, Kaiser Franz I. übermittelt Graf Taaffe einen Vortrag der vereinigten Hoflanzlei wegen der Teilung des Vermögens des ehemaligen Theatiner Kollegiums zu Lemberg. 
Konsulatsarchive" (GKA). Podzespół ten zawiera archiwalia utworzone przez powstałe w 1848 roku Poselstwo i Konsulat (Gesandtschaft und Konsulat), które wraz z Ministerstwem Spraw Zagranicznych (Ministerium des Äußern) zajmowało się polityką zagraniczną cesarstwa, przejmując kompetencje Kancelarii Stanu ${ }^{14}$. W części tej znajduje się grupa źródeł nosząca nazwę „Rom Geistliche Agentie Akten”, dotycząca spraw Kościoła katolickiego w latach 1720-1909 (w przeważającej części odnoszą się one do okresu po 1848 roku) ${ }^{15}$ i obejmująca korespondencję dyplomatyczną z Watykanem ${ }^{16}$.

W dosyć pokaźnej grupie źródeł dotyczących nominacji biskupich („Bischofernennungen") w monarchii habsburskiej znalazły się dokumenty związane z obsadą arcybiskupstwa lwowskiego obrządku ormiańskiego. Nie są one ułożone według diecezji lub obrządku, ale według lat, w których dani duchowni otrzymywali urząd. Są w nich zatem procesy informacyjne, stanowiska władz państwowych i kościelnych, a czasami także odnośna korespondencja. Listę ormiańskokatolickich arcybiskupów lwowskich, których dotyczą te materiały ${ }^{17}$, rozpoczyna Kajetan Augustyn Warteresiewicz (nominacja w 1819 roku) ${ }^{18}$, następnie Samuel Cyryl Stefanowicz ${ }^{19}$, Grzegorz Michał Szymonowicz ${ }^{20}$, Grzegorz Józef Romaszkan ${ }^{21}$, Izaak Mikołaj Isakowicz ${ }^{22}$ i Józef Teodorowicz ${ }^{23}$. Ponadto

${ }^{14}$ Szerzej o zasobach archiwum Ministerstwa Spraw Zagranicznych po 1848 roku zob.: R. Stropp, Die Akten des k. u. k. Ministeriums des Äußern 1848-1918, „Mitteilungen des Österreichischen Staatsarchivs", 20, 1967, s. 389-506; 30, 1977, s. 398-444; 32, 1979, s. 306349; 33, 1980, s. 357-415; 34, 1981, s. 411-456. Przewijają się w nich kwestie kościelne, w tym dotyczące obrządku ormiańskokatolickiego, ale zespołu tego nie przejrzałem.

15 Informacja o podzespole: https://www.archivinformationssystem.at/detail.aspx?ID=710.

${ }^{16}$ Część tych źródeł doczekała się publikacji lub opracowania. Zob. F. Engel-Jánosi, Österreich und der Vatikan 1846-1918, 1-2, Graz-Wien-Köln 1958-1960; idem, Die politische Korrespondenz der Päpste mit den österreichischen Kaisern 1804-1918, Wien-München 1964, Veröffentlichungen zur Kirchengeschichte Österreichs, 2.

17 Wypisy prasowe traktujące o sakrach arcybiskupów lwowskich obrządku ormiańskiego w XIX wieku zebrał K. R. Prokop, Wypisy z XVIII- i XIX-wiecznej prasy periodycznej na temat sakr biskupich Kościoła katolickiego z historycznych ziem polskich, „Biuletyn Biblioteki Jagiellońskiej”, 62, 2012, s. 27 (Jakub Stefan Augustynowicz), 37 (Isakowicz), 54-55 (Romaszkan), 58 (Stefanowicz), 60-61 (Szymonowicz), 61-62 (Warteresiewicz).

18 ÖSA: HHSA, Diplomatie und Außenpolitik 1848-1918, GKA, Rom Geistliche Agentie Akten, 27.1 (rok 1820).

19 ÖSA: HHSA, Diplomatie und Außenpolitik 1848-1918, GKA, Rom Geistliche Agentie Akten, 31.1 (rok 1832).

20 ÖSA: HHSA, Diplomatie und Außenpolitik 1848-1918, GKA, Rom Geistliche Agentie Akten, 154-1 (lata 1857 i 1858). W katalogu zapisany jako Szymovich i Szymonovicz.

${ }^{21}$ ÖSA: HHSA, Diplomatie und Außenpolitik 1848-1918, GKA, Rom Geistliche Agentie Akten, 158.1 (rok 1876).

${ }^{22}$ ÖSA: HHSA, Diplomatie und Außenpolitik 1848-1918, GKA, Rom Geistliche Agentie Akten, 160.1 (rok 1882).

${ }^{23}$ ÖSA: HHSA, Diplomatie und Außenpolitik 1848-1918, GKA, Rom Geistliche Agentie Akten, 205.1 (rok 1901). 
w grupie „Bischofernennungen” znajdują się materiały dotyczące nominacji duchownych ormiańskich na szambelanów papieskich i kanoników kapituły lwowskiej: Kajetana Maramorosza ${ }^{24}$, Jakuba Moszory ${ }^{25}$, Kajetana Kajetanowicza ${ }^{26}$ i Dominika Barącza ${ }^{27}$. Jest też udokumentowana nominacja biskupia Franciszka Ksawerego Zachariasiewicza, Ormianina, profesora i rektora Uniwersytetu Lwowskiego, badacza dziejów Ormian polskich ${ }^{28}$.

Wyszukiwanie danych w katalogu archiwum jest nieco utrudnione, gdyż niejednokrotnie nazwiska duchownych z Galicji pisane są niepoprawnie, nie zawsze też dokładnie zaznaczono, że chodzi o duchownego ormiańskokatolickiego. Nie jest zatem wykluczone, że niektóre osoby umknęły mojej uwadze. Badacz, który zajmuje się biografiami poszczególnych kapłanów, musi zatem cierpliwie i dokładnie przeglądać ów inwentarz.

W tym miejscu należy wspomnieć, że ze źródeł tych korzystał już Bolesław Kumor w opracowaniach poświęconych obsadom biskupstw galicyjskich ${ }^{29}$. Oddzielne opracowanie dedykował obsadzie arcybiskupstwa ormiańskokatolickiego we Lwowie, ale odwołał się w nim tylko do niektórych wzmiankowanych tu źródeł przy omawianiu trzech ostatnich nominacji: Romaszkana, Isakowicza i Teodorowicza ${ }^{30}$. Z kolei Edith Saurer, której jedna z książek dotyczyła politycznych aspektów nominacji biskupich w monarchii austro-węgierskiej w latach 1867-1903, wykorzystując omawianą tutaj grupę źródeł, poświęciła rozdział nominacjom galicyjskim, ale głównie biskupów łacińskich i greckokatolickich, zaś ormiańskokatolickich potraktowała w jednym, krótkim akapicie. Wspomnia-

${ }^{24}$ ÖSA: HHSA, Diplomatie und Außenpolitik 1848-1918, GKA, Rom Geistliche Agentie Akten, 154.1 (rok 1856). W inwentarzu komputerowym: Maramoross. Bulla papieża Piusa IX z 15 stycznia 1856 roku, mianująca Kajetana Maramorosza szambelanem papieskim, znajduje się w Archiwum Fundacji Kultury i Dziedzictwa Ormian Polskich (Dokumenty aktowe, nr 7).

25 ÖSA: HHSA, Diplomatie und Außenpolitik 1848-1918, GKA, Rom Geistliche Agentie Akten, 205.1 (rok 1901).

26 ÖSA: HHSA, Diplomatie und Außenpolitik 1848-1918, GKA, Rom Geistliche Agentie Akten, 160.1 (rok 1880).

27 ÖSA: HHSA, Diplomatie und Außenpolitik 1848-1918, GKA, Rom Geistliche Agentie Akten, 159.1 (rok 1877). W katalogu komputerowym: Barasz.

28 ÖSA: HHSA, Diplomatie und Außenpolitik 1848-1918, GKA, Rom Geistliche Agentie Akten, 67.1 (rok 1836 - na biskupa tarnowskiego, rok 1840 - na biskupa przemyskiego obrządku łacińskiego).

29 B. Kumor, Obsada biskupstwa krakowskiego w latach 1790-1914, „Analecta Cracoviensia”, 8, 1976, s. 321-343; idem, Obsada metropolii lwowskiej obrzadku łacińskiego w latach 1780-1850, „Folia Societatis Scientiarum Lublinensis. Humanistyka”, 18, 1976, 2, s. 95-105; idem, Obsada metropolii lwowskiej obrzadku lacińskiego w latach 1772-1918, „Analecta Cracoviensia”, 9, 1977, s. 447-468; id em, Obsada biskupstwa tarnowskiego w latach 1783-1807, „Analecta Cracoviensia”, 13, 1981, s. 425-441.

${ }^{30}$ B. Kumor, Obsada arcybiskupstwa ormiańskokatolickiego we Lwowie w latach niewoli narodowej (1772-1918), „Analecta Cracoviensia”, 26, 1994, s. 371-384. 
ła tylko, że w Galicji takowi byli i wymieniła trzech (Romaszkana, Isakowicza i Teodorowicza), którzy kierowali archidiecezją ormiańską we Lwowie w badanym przez nią okresie ${ }^{31}$.

W omawianym podzespole znajdują się jeszcze dwa kartony zawierające korespondencję władz austriackich z diecezjami galicyjskimi wszystkich trzech obrządków, w tym z ormiańskokatolicką. Pierwszy karton dotyczy lat 1833-1843 ${ }^{32}$, drugi - 1844-1855 ${ }^{33}$. Znajdujące się w nich dokumenty wiążą się w większości z udzielaniem dyspens w sprawach małżeńskich. Pojawiają się w nich następujące nazwiska: Abrahamowicz, Agospowicz, Amirowicz, Antoniewicz, Bogdanowicz $^{34}$, Czajkowski (Czaykowski), Donigiewicz, Holub, Hołubasz, Gatkiewicz (Gątkiewicz?), Janowicz, Jędrzejewicz, Jędrzejowicz, Krzeczunowicz, Łukasiewicz, Markiewicz, Mikołajewicz, Mikuli, Moszoro, Nikorowicz, Passakas, Petrowicz, Pinterhoffer, Romaszkan, Szymonowicz, Theodorowicz, Teodorowicz, Torosiewicz, Wartanowicz. Źródła te są przede wszystkim ważne dla badań nad społecznością ormiańską w Galicji. Mogą w pewnym stopniu uzupełnić bądź pogłębić podjęte już w Polsce studia genealogiczne i demograficzne ${ }^{35}$.

W HHSA znajduje się także zespół „Kabinettsarchiv” (KA), którego podzespół „Kaiser-Franz-Akten” (KFA) posiada kilka jednostek dotyczących Kościoła ormiańskokatolickiego w Galicji. Nie miałem okazji ich przejrzeć, chciałbym jednak zwrócić uwagę na kartony z raportami i wizytacjami biskupimi, w tym między innymi arcybiskupa Samuela Cyryla Stefanowicza z 1833 roku $^{36}$. Znamy zawartość tego rodzaju źródeł, gdyż Jan Mikrut omówił i wydał wizytacje niektórych galicyjskich hierarchów z pierwszych dekad XIX stulecia: metropolity lwowskiego obrządku łacińskiego Andrzeja Alojzego Ankwicza z 1822 roku, biskupa tynieckiego i tarnowskiego Tomasza Grzegorza Zieglera z przełomu lat

31 E. Saurer, Die politischen Aspekte der österreichischen Bischofsernennungen 18671903, Wien-München 1968, Veröffentlichungen zur Kirchengeschichte Österreichs, 6, s. 179. Na końcu książki podała bardzo krótkie notki o poszczególnych biskupach, w tym Isakowiczu (s. 245), Romaszkanie (s. 252) i Teodorowiczu (s. 254).

32 ÖSA: HHSA, Diplomatie und Außenpolitik 1848-1918, GKA, Rom Geistliche Agentie Akten, 84.1, Lemberg (ritus latini, ritus armeni; ritus graeci), Krakau, Przemysl, Stanislawow, Tarnow und Gurk, 1833-1843.

${ }^{33}$ Ibidem, 85.1, Lemberg (ritus latini, ritus armeni; ritus graeci), Krakau, Przemysl, Stanislawow, Tarnow und Gurk, 1844-1855.

34 Znajduje się tam na przykład dokumentacja dyspensy Roberta Bogdanowicza i Serafiny z Bogdanowiczów, których historię mariażu opisał na swój sposób Marian Rosco Bogdanowicz (Wspomnienia, wstęp A. Knot, oprac. J. Ginte1, 1, Kraków 1959, s. 10-11).

35 Zob. F. Wasyl, Ormianie w przedautonomicznej Galicji. Studium demograficzno-historyczne, Kraków 2015, Studia Galicyjskie, 4.

36 ÖSA: HHSA, KA, KFA, 218-5, Berichte des Armenischen Erzbischofs zu Lemberg (1833). W tym samym kartonie (nr 1-4) są także raporty biskupów z Litomierzyc (Czechy), Chorwacji i Włoch oraz arcybiskupów lwowskich: łacińskiego (z lat 1817-1833) i greckokatolickiego (1809). 
1822 i 1823 oraz biskupa tarnowskiego Franciszka Pischteka z 1832 roku $^{37}$. Można więc mieć nadzieję, że raport arcybiskupa Stefanowicza ma podobny charakter i daje obraz ówczesnego stanu archidiecezji ormiańskiej.

Wiele źródeł do dziejów Kościoła ormiańskokatolickiego w Galicji znajduje się także w drugim ze wspomnianych oddziałów ÖSA, tj. w AVA. Większość z nich weszła w skład zespołu pt. „Kultus und Unterricht” (skrót: Kultus). W zbiorze tym znajdują się archiwalia dotyczące instytucji różnych wyznań religijnych, w tym należących do Kościoła katolickiego diecezji, parafii, cmentarzy, klasztorów, seminariów duchownych, stowarzyszeń i innych instytucji działających na terenie całego imperium Habsburgów. Do 1848 roku sprawami kultu religijnego zajmowało się Ministerstwo Spraw Wewnętrznych (Ministerium des Innern ${ }^{38}$, jednak potem przekazano je Ministerstwu Edukacji, które wówczas zmieniło nazwę na Ministerstwo Wyznań i Oświaty (Ministerium für Kultus und Unterricht) i funkcjonowało pod nią do końca istnienia monarchii ${ }^{39}$. Stąd też rok 1848 stanowi ważną cezurę. Archiwalia dotyczące kultu, które zostały wytworzone przed tą datą, zostały zgromadzone w podzespole zatytułowanym „Alter Kultus” (skrót: AK), natomiast powstałe później - jako „Neuer Kultus” (NK). Oba posiadają dwa działy (grupy): kult katolicki („Katholischer Kultus”) i kult niekatolicki („Akatolischer Kultus”), do którego zaliczono Kościół ewangelicki, prawosławny i judaizm. Mnie interesowały działy dotyczące kultu katolickiego w obu podzespołach ${ }^{40}$.

37 Zob. J. Mikrut, Bischöfe aus Galizien berichten an Kaiser Franz I. Ein Beitrag zur Geschichte der Katholischen Kirche in der Habsburgermonarchie, Wien 1995; idem, Die galizische Diözese Tyniec-Tarnów in den Visitationsberichten von Bischof Thomas Gregorius Ziegler (1822-1827), Wien 2009.

${ }^{38}$ Por. W. Goldinger, Die Zentralverwaltung in Cisleithanien - Die zivile gemeinsame Zentralverwaltung, w: Die Habsburgermonarchie 1848-1918, 2, Verwaltung und Rechtswesen, red. A. Wandruszka, P. Udbanitsch, Wien 1975, s. 125-128.

39 Szerzej na temat tego ministerstwa zob.: R. H. Hernitt, Ministerium für Kultus und Unterricht, w: Österreichisches Staatswörterbuch, 3, red. E. Mischler, J. Ulbrich, Wien 1907, s. 625-630; J. Musil, Zur Geschichte des österreichischen Unterrichtsministeriums 1848-1948, w: 100 Jahre Unterrichtsministerium 1848-1948. Festchrift des Bundesministeriums für Unterricht in Wien, red. E. Loebenstein, Wien 1948, s. 7-36; R. Höslinger, Das Kultuswesen in der Zeit von 1867-1948, w: 100 Jahre Unterrichtsministerium, s. 427-233; H. Spreitzer, Das österreichische Unterrichtsministerium 1848-1960, „Österreich in Geschichte und Literatur", 4, 1960, s. 8-14; R. Mester, Österreichs Unterrichtsverwaltung und Unterrichtsanstalten 1760-1960, w: 200 Jahre Österreichische Unterrichtsverwaltung 17601960. Festschrift des Bundesministeriums für Unterricht in Wien, red. A. Kolbabek, Wien 1960, s. 67-98; W. Goldinger, Die Zentralverwaltung in Cisleithanien, s. 130-133. Niewielki fragment spuścizny po tym ministerstwie znajduje się w Archiwum Głównym Akt Dawnych w Warszawie (por. S. Ciara, C. K. Ministerstwo Wyznań i Oświaty (K. k. Ministerium für Kultus und Unterricht), w: Archiwum Główne Akt Dawnych w Warszawie. Przewodnik po zasobie, 2, Epoka porozbiorowa, Warszawa 1998, s. 653-658.

${ }^{40}$ W 1899 roku o kwerendzie w archiwum tego ministerstwa pisał Chotkowski, którego interesowały przede wszystkim kasaty klasztorów w okresie józefińskim: W. Chotkowski, 
W „Alter Kultus” znalazłem dwa kartony dotyczące diecezji galicyjskich, w których są źródła związane z archidiecezją ormiańskokatolicką we Lwowie. Pierwszy z nich nosi numer 216 i jest podzielony na trzy części: 1) rzymskokatolicka kapituła we Lwowie w latach 1787-1847; 2) katedra greckokatolicka w tymże mieście (1783-1831); 3) arcybiskupstwo lwowskie obrządku ormiańskokatolickiego w latach 1773-1820 ${ }^{41}$. W tej ostatniej znajdują się między innymi dokumenty związane z nominacją na arcybiskupstwo Jakuba Waleriana Tumanowicza, Jana Jakuba Szymonowicza ${ }^{42}$ i Kajetana Warteresiewicza ${ }^{43}$. Z tych materiałów korzystał już ks. Kumor we wspomnianym artykule o obsadzie arcybiskupstwa. W tymże zbiorze znajduje się także list arcybiskupa Tumanowicza - pierwszego ordynariusza Ormian polskich, który objął rządy za panowania austriackiego w 1783 roku $^{44}$ - datowany na 12 czerwca 1790 roku. Jest to homagium złożone cesarzowi Leopoldowi II. W tym samym zbiorze znajduje się jeszcze kilka pism w języku łacińskim i włoskim, dotyczących sytuacji Kościoła ormiańskokatolickiego w roku 1773. Jedno z nich (z 25 września) podpisał arcybiskup Jakub Stefan Augustynowicz. Inne pismo podpisało sześciu kapła-

Ze studyów $w$ archiwum ministerstwa wyznań $i$ oświaty $w$ Wiedniu do historyi klasztorów w Galicyi, „Sprawozdanie z Czynności i Posiedzeń Akademii Umiejętności w Krakowie”, 4, 1899, 9, s. 6-9 (przedruk w: idem, Kasaty klasztorów w Galicji. Wybór prac, wstęp i wyd. A. Gąsior, J. Królikowski, Kraków 2019, Dziedzictwo Kulturowe po Skasowanych Klasztorach, 10, s. 17-20).

41 ÖSA: AVA, Kultus, AK, Katholisch, 216.3, Erzbistum Lemberg, rit. arm. (1773-1820).

${ }^{42}$ G. Petrowicz (La Chiesa armena in Polonia, s. 242-273) i T. Zaleski (Stownik biograficzny duchownych ormiańskokatolickich oraz duchownych rzymskokatolickich pochodzneia ormiańskiego $w$ Polsce $w$ latach 1750-2000, Kraków 2001, s. 78) jego nazwisko piszą: „Symonowicz”. Tymczasem w omawianych tutaj dokumentach jest ono zapisane jako „Szymonowicz”. Tę drugą wersję nazwiska stosuje B. Kumor, jednak on błędnie przypisuje mu imię Józef, zamiast Jan Jakub. Nazwisko „Szymonowicz” znajdujemy też w wydawnictwie źródłowym rejestrującym biskupów katolickich mianowanych przez Stolicę Apostolską pt. Hierarchia catholica medii et recentioris aevi, sive Summorum pontificum - S. R. E. cardinalium ecclesiarum antistitum series e documentis tabularii praesertim Vaticani collecta, digesta, edita, 7, A pontificatu Pii PP. VII (1800) usque ad pontificatum Gregorii PP. XVI (1846), wyd. R. Ritzler, P. Sefrin, Patavii 1968, s. 236. Z kolei Österreichisches Biographisches Lexikon 1815-1950 (14, Graz-Köln 2015, s. 179) podaje dwie wersje: „Symonowicz” i „Simonowicz”, ale nie tę, którą posługuje się austriacka dokumentacja urzędowa.

${ }^{43}$ T. Kuster w artykule poświęconym podróży cesarza Franciszka I do Włoch w 1819 roku omawia także jego wizytę w Stolicy Apostolskiej i kwestie obsady biskupstw na terenie monarchii, wspominając przy tej okazji ks. Warteresiewicza. Błędnie jednak pisze, że został on powołany na urząd łacińskiego arcybiskupa lwowskiego. Powołuje się na materiały wiedeńskiej nuncjatury, znajdujące się w Tajnym Archiwum Watykańskim, natomiast w ogóle nie przywołuje dokumentacji wiedeńskiej (T. Kuster, Die italienreise Kaiser Franz' I von Österreich 1819, „Römische Historische Mitteilungen”, 46, 2004, s. 318).

${ }^{44}$ Sakrę otrzymał jako biskup kamieniecki i koadiutor arcybiskupa lwowskiego 17 maja 1772 roku, czyli jeszcze w czasach, gdy archidiecezja lwowska pozostawała w granicach Polski. 
nów - byli to: Mikołaj Kołczan, Piotr Boosiewicz, Stanisław Michalewicz, Antoni Norses, Jakub Senkowicz i Jan Jakub Szymonowicz, późniejszy arcybiskup ormiański we Lwowie. Spora część tej jednostki archiwalnej dotyczy kongrui (tj. uposażenia) duchowieństwa.

Drugi karton, o numerze 217, składa się z pięciu części, z których cztery pierwsze dotyczą Kościoła ormiańskokatolickiego: 1) archidiecezja w latach 1824$1845^{45}$; 2) dom kapitulny w latach $1768-1844^{46}$; 3) kapituła honorowa w latach $1795-1842^{47}$; 4) katedra w latach $1812-1845^{48}$. Ostatnia, piąta część, traktuje już o diecezji przemyskiej obrządku łacińskiego w latach 1776-1784 ${ }^{49}$. Podobnie jak w poprzednim kartonie, tutaj również znajdują się materiały dotyczące nominacji arcybiskupów ormiańskich, w kolejnych latach, na przykład Samuela Cyryla Stefanowicza. Szczególnie interesująca jest podpisana przez tegoż przysięga na wierność dworowi cesarstwa austriackiego w dwóch językach: niemieckim i polskim:

Ja, Samuel Stefanowicz, przysięgam w uświęcone i przenajświętsze Imię Boga i ślubuję Najjaśniejszemu Monarsze i Panu Franciszkowi Pierwszemu z Bożej łaski Cesarzowi Austriackiemu, Królowi Jeruzalemskiemu, Węgierskiemu, Czeskiemu, Galicyjskiemu i t. d. moje mu najmiłościwszemu Cesarzowi, Królowi, Monarsze i Panu, że póki życia mojego temuż wiernym i poddanym zostać, dobro Państwa i służby Jego podług wszystkich sił wspierać, do żadnych schadzek, przedsięwzięć lub zmów, któreby na szkodę pierwszego lub drugiej wypaść mogły, nie należyć, owszem, jak daleceby coś podobnego do mojej wiedzy dojść miało, natychmiast do Jego C. K. Mości odkryć. Przysięgam, iż do żadnego tajnego towarzystwa ani bractwa, bądź kraju ani zagranicą wplątany nie jestem, ani też na przyszłość w podobne tajemne związki i pod jakimbądźkolwiek pozorem nie udam się. Tak mi Boże dopomóż, i święte ewangelie, których się tu dotykam ${ }^{50}$.

Ponadto w niektórych dokumentach (całego kartonu) pojawiają się następujący duchowni ormiańskokatoliccy: Antoni de Bołoz Antoniewicz, Jakub Axento-

45 ÖSA: AVA, Kultus, AK, Katholisch, 217.1, sygn. 33, Erzbistum Lemberg, rit. arm. (1824-1845).

46 ÖSA: AVA, Kultus, AK, Katholisch, 217.2, sygn. 33, Erzbistum Lemberg, rit. arm. Domkapitel (1786-1844).

${ }^{47}$ ÖSA: AVA, Kultus, AK, Katholisch, 217.3, sygn. 33, Erzbistum Lemberg, rit. arm. Ehrendomherren (1795-1842).

48 ÖSA: AVA, Kultus, AK, Katholisch, 217.4, sygn. 33, Erzbistum Lemberg, rit. arm. Domkirche (1812-1845).

49 ÖSA: AVA, Kultus, AK, Katholisch, 217.5, sygn. 33, Bistum Przemysl, rit. lat. (1776-1784).

50 ÖSA: AVA, Kultus, AK, Katholisch, 217.1. (jednostka nie posiada paginacji). Przysięga podpisana została własnoręcznie przez arcybiskupa i datowana we Lwowie 8 czerwca 1832 roku. Pisownia uwspółcześniona. 
wicz, Grzegorz Barącz ${ }^{51}$, Mikołaj Barącz ${ }^{52}$, Grzegorz Birar, Grzegorz Bogdanowicz, Dawid Dawidowicz, Dominik Donigiewicz, Kajetan Maromorosz, Kajetan Mikołajewicz i syndyk (banku Mons Pius lub biskupi) Kopczyński, o którym mowa w dokumencie z 8 lipca 1838 roku.

W kartonie nr 930 znajduje się nieduża jednostka odnosząca się do zakonu teatynów, tak przecież silnie związanego z Ormianami ${ }^{53}$. Zawiera ona materiały dotyczące klasztorów teatyńskich, a w szczególności zakonników, przyznawanych im pensji, emerytur, prezentów itd.

Jeżeli chodzi o podzespół „Neuer Kultus”, natrafiłem w nim jedynie na jeden karton, w którym znalazło się nieco źródeł do ormiańskokatolickiej archidiecezji lwowskiej. Chodzi tu o karton nr 79, zatytułowany „Kirchliche Verwaltung, Bischöfliche Versammlung etc." (Administracja kościelna, zgromadzenie biskupów itp.). Składa się on z 38 mniejszych jednostek, wśród których nr 12 dotyczy archidiecezji lwowskiej wszystkich 3 obrządków ${ }^{54}$ i zawiera między innymi notatki dotyczące dziejów lwowskiej archidiecezji ormiańskokatolickiej, w większości spisanych jedną ręką (nie udało się ustalić czyją).

W obu podzespołach znajdujemy też kartony z materiałami o parafiach katolickich w Galicji („Pfarren in Galizien”). W podzespole „Alter Kultus” posiadają one numery od 495 do 525 (dawna sygnatura 47), natomiast w „Neuer Kultus” odnoszą się do nich numery od 604 do 679 (dawna sygnatura podobnie o numerze 47). Poza kilkoma pierwszymi kartonami, które zawierają ogólne źródła dotyczące organizacji parafii, prawa patronatu itp., pozostałe są ułożone alfabetycznie według miejscowości. W ramach miejscowości brak rozróżnienia na poszczególne obrządki; czasami są one wyszczególnione, innym razem przemieszane. W Galicji działało dziewięć parafii obrządku ormiańskiego: we Lwowie, Brzeżanach, Stanisławowie, Tyśmienicy, Horodence, Kutach, Śniatynie i Czerniowcach i kapelania misyjna w Suczawie. Ponadto przez pewien tylko czas istniały parafie w Obertynie (przekształcona w łacińską w 1796 roku) ${ }^{55}$ i Zamościu (zlikwidowana jeszcze przed utratą tego miasta przez Austrię w 1809 roku). W trakcie kwerendy przejrzałem jedynie kartony: Brzeżany (tylko w podzespole

51 W źródle: Barąz.

52 W źródle: Barancz.

53 ÖSA: AVA, Kultus, AK, Katholisch, 930.9, sygn. 107, Klöster allgemein - Theatiner (1783-1791). Przeprowadzając kwerendę w ÖSA w marcu tego roku, nie dotarłem do tej jednostki. Jej fotografie otrzymałem od dr. Tomasza Krzyżowskiego, któremu w tym miejscu składam serdeczne podziękowanie.

54 ÖSA: AVA, Kultus, NK, Kath Akten, 79.12, sygn. 27, Erzbistum Lemberg (rit. gr., rit. lat., rit. arm.).

${ }_{55}$ Por.: W. Chotkow ski, Historya polityczna Kościoła w Galicyi za rządów Marii Teresy, 2, Kraków 1909, s. 504; B. R [ozwadow ski], Obertyn, w: Stownik geograficzny Królestwa Polskiego i innych krajów stowiańskich, 7, red. B. Chlebowski, W. Walewski, Warszawa 1886, s. 323; S. B arąc z, Rys dziejów ormiańskich, Tarnopol 1869, s. 163. 
$\mathrm{NK})^{56}$, Łysiec (tylko NK) ${ }^{57}$, Stanisławów (tylko AK) ${ }^{58}$ i Tyśmienica (AK i NK) ${ }^{59}$. Znalazłem tam szczątkowe materiały i nie zawsze dotyczące spraw ormiańskich. Na przykład karton „Brzeżany” zawiera zaledwie 15 stron dokumentów, wszystkie na temat parafii greckokatolickiej z lat 1902-1907. Możliwe, że jakieś materiały odnośnie do Ormian brzeżańskich znalazły się w podzespole „Alter Cultus”. Również w kartonie dotyczącym Stanisławowa w podzespole „Alter Cultus” nie ma archiwaliów odnoszących się do tamtejszej parafii ormiańskiej. Co prawda wzmiankowani są tam dwaj duchowni ormiańskiego pochodzenia, jednak jako duchowni rzymskokatoliccy, gdyż zmienili obrządek: proboszcz parafii rzymskokatolickiej w Śniatynie Deodat Maramorosz ${ }^{60}$ i proboszcz parafii łacińskiej w Stanisławowie Jakub Mikołajewicz. W jednostce dotyczącej Tyśmienicy (w części „Alter Kultus”) znajdujemy już więcej informacji o tamtejszej parafii ormiańskiej. Oprócz niej działała tam także parafia łacińska, która została inkorporowana do tyśmienickiego klasztoru dominikanów. Wielokrotnie pojawiają się proboszczowie ormiańscy: Antoni Borkowski, kierujący parafią w latach 1803 1820, i Jan Krzysztofowicz, jego następca od 1820 aż do śmierci w 1849 roku. W części „Neuer Kultus” jednostka dotycząca Tyśmienicy posiada materiały odnoszące się do budowy i uposażenia kaplicy cmentarnej, którą ufundowała ormiańska rodzina Bochdanowiczów ${ }^{61}$ - Stefan i jego żona Rypsyma. Materiały te pochodzą z lat pięćdziesiątych XIX stulecia, kiedy proboszczem był ks. Grzegorz Moszoro. Za jego czasów doszło do pożaru kościoła - to on podjął się jego odbudowy i część jednostki właśnie tego dotyczy. Znajduje się w niej między innymi prośba ks. Kajetana Kajetanowicza, administratora ormiańskokatolickiej parafii katedralnej i dyrektora Bursy Ormiańskiej im. Józefa Torosiewicza we Lwowie,

${ }^{56}$ ÖSA: AVA, Kultus, NK, Kath Akten, 608.3, sygn. 47, Be - Bednarowka (Bednarow), Bedrykowce, Bereky dolne, Beremiany, Berhometh (inkl. Ausweistabelle), Berlohy, Blesza, Brzeszcze, Brzezany, Brzezie (Bzezie), Bereznicza Szlachecka, 1850-1918, bez paginacji. Za udostępnienie fotografii dziękuję dr. Tomaszowi Krzyżowskiemu.

57 ÖSA: AVA, Kultus, NK, Kath Akten, 640.2, sygn. 47, Li - Liatacz, Libusza (Holzkirche), Lichtenberg, Liezkowce, Lipa, Lipica gorne, Lipinki, Lipinski, Lipniki, Lipowiec, Lipsko, Lisia gora, Lisiatycze, Lysiec, Lisko, Liski, Liskowate, Lisowce, Liszki, Lisznia, Litynia, Lisznia, bez paginacji (1906-1916).

58 ÖSA: AVA, Kultus, AK, Katolisch, 520.1:, sygn. 47, Orte Su-Sz, Sta, bez paginacji.

59 ÖSA: AVA, Kultus, AK, Katolisch, 522.1, sygn. 47, Orte Ti-U, bez paginacji; ÖSA: AVA, Kultus, NK, Kath Akten, 668.2, sygn. 47: Ti - Trzciana, Trzcianiec (Trzcianice), Trybuchowce, Tyczin, Twierdza, Tylawa, Tylicz, Tylmanowa, Tymbark, Tymova (Timowa), Tryncza, Tyniatyska, Trzcinica, Tyniec, Tyniowa, Tynow, Tynowa (Tynower), Tyrawa-woloska, Tysmieniczany, Tysmienica, Tysmienice (Tysmienitz), Tysowice (Tysowica), Tyniatyska, Tisstin, Tyszkowce, Tindiow, bez paginacji.

${ }^{60}$ Zmarł 7 marca 1832 roku (Catalogus universi venerabilis cleri saecularis et regularis Archidioecesos Leopolitanae pro anno Domini MDCCCXXXIII, [Leopoli 1832 lub 1833], s. 137, jako Maramoross).

61 Tak w aktach. 
skierowana do konsystorza arcybiskupiego w roku 1880, o przydzielenie z funduszy banku Mons Pius dotacji na restaurację świątyni. W tym samym podzespole znajduje się jednostka archiwalna, w której znajdujemy nieco materiałów dotyczących parafii ormiańskokatolickiej w Łyścu. Jeden dokument pochodzi z 1907 roku, kiedy proboszczem był Karol Szczepański, który zarządzał obiema miejscowymi parafiami: ormiańską (od 1885 roku) i łacińską (od 1889 roku). Po jego śmierci proboszczem obu parafii był Kajetan Amirowicz. Dotyczy go obszerny dokument z 1908 roku. Pozostałe traktują głównie o restauracji kościoła w latach 1913-1914, za probostwa ks. Andrzeja Kasprzykiewicza ${ }^{62}$.

W zespole „Unterricht und Kultus” znalazłem jeszcze karton z materiałami dotyczącymi szkół ormiańskich we Lwowie. Warto przypomnieć, że do 1848 roku administracją oświaty w Austrii zajmowała się powstała w 1760 roku Nadworna Komisja Studiów (Studienhofkommission, skrót: SHK). Podlegały jej zarówno uniwersytety, jak też państwowe, prywatne i wyznaniowe szkoły wszystkich stopni ${ }^{63}$. To właśnie w zachowanej po niej spuściźnie aktowej znalazły się źródła na temat szkolnictwa żeńskiego w klasztorach i konwiktach na terenie Galicji. Materiały te znajdują się w kartonie 103, a trzecia jego część dotyczy szkoły dla dziewcząt prowadzonej przez benedyktynki ormiańskie we Lwowie ${ }^{64}$. Dokumenty te dotyczą spraw finansowych, takich jak utrzymanie szkoły (np. ogrzewanie), pensje kadry nauczycielskiej, która w przeważającej części składała się z zakonnic, a także liczebność kształcących się w niej dziewcząt. Źródła te wykorzystał już ks. Chotkowski w studium o klasztorach żeńskich w Galicji w latach 17731848, w rozdziale poświęconym benedyktynkom obrządku ormiańskiego ${ }^{65}$. Cytuje je także Isabel Röskau-Rydel ${ }^{66}$. Aby zakonnice same mogły nauczać, musiały

${ }^{62}$ Wcześniej był kapłanem w zakonie karmelitów trzewiczkowych (imię zakonne Michał, święcenia kapłańskie w 1893 roku), przeorem klasztoru i administratorem parafii rzymskokatolickiej w Bołszowcach. W 1906 roku został inkardynowany do archidiecezji lwowskiej obrządku łacińskiego. Por. T. Krzyżow ski, Archidiecezja lwowska obrządku ormiańskokatolickiego w latach 1902-1938, Kraków 2018, s. 269, 271, mszps rozprawy doktorskiej, Uniwersytet Papieski Jana Pawła II w Krakowie.

${ }^{63}$ Szerzej o administracji szkolnej w Austrii w XIX w. zob.: F. Walter, Die zentrale Schulverwaltung in Österreich 1760-1848, „Österreich in Geschichte und Politik”, 4, 1960, s. 2-8; H. Engelbrecht, Geschichte des österreichischen Bildungswesens. Erziehung und Unterricht auf dem Boden Österreichs, 3, Von der frühen Aufklärung bis zum Vormärz, Wien 1984.

${ }^{64}$ ÖSA: AVA, Unterricht, SHK, Teil 1, 103.3, Lemberg, Armenierinnen (weibliche Klosterschule) (1786-1790).

${ }^{65}$ Zob. W. Chotkow ski, Historya polityczna dawnych klasztorów panieńskich, s. 239261. Ów historyk wykorzystał znacznie więcej archiwaliów, w których znajdują się wzmianki o benedyktynkach ormiańskich we Lwowie, ale ich odnalezienie wymaga czasu, tym bardziej że gdy o nich pisal, nosiły inne sygnatury.

${ }_{66}$ Por. I. Röskau-Rydel, Kultur an der Peripherie des Habsburger Reiches. Die Geschichte des Bildungswesens und der kulturellen Einrichtungen in Lemberg von 1772 bis 
mieć ukończony 14. rok życia. Zarówno nauczycielki zakonne, jak i świeckie otrzymywały państwową pensję. Klasztor we własnym zakresie pokrywał koszty ogrzewania i sprzątania. Gubernium lwowskie podkreślało, iż nauczycielkom trzeba dobrze płacić, gdyż w innym wypadku udają się one do pracy w domach szlacheckich. W piśmie z 17 września 1790 roku mowa jest o 400 dziewczętach uczących się w szkole. Zakonnicom bardzo zależało na utrzymaniu szkoły, gdyż od tego uzależnione było istnienie ich klasztoru. W uzasadnieniu podkreślano, że powodem egzystencji klasztorów jest prowadzenie szkół, bo w innym wypadku byłyby niepotrzebne. Już w 1787 roku zastanawiano się nad przeniesieniem zakonnic w inne miejsce i przerobieniem całego klasztoru na sale lekcyjne, w tym refektarza na dwie duże sale, z których mogłaby korzystać szkoła. Trzy lata później nie powstały dokładne plany, podkreślano jedynie, że klasztor jest potrzebny, chociaż zauważono także, że żyjące w nim siostry (było ich wówczas 19) są w podeszłym wieku i schorowane. Władze zalecały, aby przyjmować nowicjuszki nadające się do pracy pedagogicznej. Gubernium, popierające szkołę benedyktynek ormiańskich, uzasadniając jej dalsze istnienie, podawało następujące powody: może przyczynić się do kształtowania nacji ormiańskiej, do pogłębiania znajomości języka niemieckiego wśród kobiet i przez to do głębszej germanizacji społeczeństwa, w końcu do wzrostu wykształcenia lwowskich kobiet (podkreślano, że w mieście jest mało kobiet wykształconych), a co za tym idzie - powiększania żeńskiej kadry pedagogicznej.

Kolejnym miejscem, w którym prowadziłem kwerendę, była biblioteka klasztoru mechitarystów (Bibliothek des Mechitharistenklosters) w Wiedniu. Placówka ta istnieje od 1805 roku. Zakonnicy przybyli tam z Triestu, gdzie od 1773 roku posiadali klasztor, ale go zamknęli, przenosząc się ze swoimi zbiorami do stolicy imperium Habsburgów ${ }^{67}$. Obecnie ośrodek wiedeński jest jednym z dwóch, które ta ormiańskokatolicka kongregacja zakonna posiada w Europie. Druga placówka znajduje się na wyspie San Lazzaro (św. Łazarza) w Wenecji. Wiedeńscy mechitaryści, poza pracą naukową i edytorską, gromadzili rękopisy ormiańskie, monety $\mathrm{i}$ inne artefakty związane z dziejami Armenii i Ormian w diasporze. Dzisiaj jest to jedna z największych skarbnic rękopisów, starych i nowych druków oraz czasopism ormiańskich. Wśród nich znalazło się także wiele pamiątek związanych z Ormianami żyjącymi na ziemiach polskich. Świadczą o tym inwentarze biblioteki klasztoru. Warto szczególnie zwrócić uwagę na zestawienia jej zasobów

1848, Wiesbaden 1993, Studien der Forschungsstelle Ostmitteleuropa an der Universität Dortmund 15, s. 94-101. Autorka przedstawia historię szkoły do 1848 roku.

${ }^{67} \mathrm{O}$ wiedeńskim klasztorze mechitarystów zob.: V. Inglisian, Die armenischen Wiener Mechitharisten, Wien 1955; R. Murray, The Armenian Mekhitarist Monastery in Vienna, „Eastern Churches Quarterly”, 11, 1956, s. 279-282; M. K. Arat, Die Wiener Mechitharisten. Armenische Mönche in der Diaspora, Wien-Köln 1990; S. K. Badzik, Mekhitarist Congregation in Vienna. A Historical Survey, Vienna 1991. 
rękopiśmiennych wydane przez Jacobusa Dashiana ${ }^{68}$, Hamazaspa Oskiana ${ }^{69}$, Heide i Helmuta Buschhausenów ${ }^{70}$, a także na katalog tych rękopisów i druków ormiańskich, które pochodzą ze Lwowa i Stanisławowa, autorstwa Nersesa Akiniana $^{71}$. Kilka lat temu o rezultatach wiedeńskich poszukiwań rękopisów ormiańskich z ziem polskich pisała Piruz Mnacakanian ${ }^{72}$. Ponadto w swej rozprawie doktorskiej pt. Kultura języka ormiańskiego $w$ dawnej Polsce ${ }^{73}$ omówiła rękopisy ormiańskie polskiej proweniencji, zaznaczając, że do klasztoru mechitarystów trafiły dzięki podróżom naukowym członków kongregacji i darom Ormian polskich, szczególnie duchownych z archidiecezji lwowskiej. Jak podkreśliła, najwięcej rękopisów zakonnicy otrzymali od arcybiskupa Isakowicza, ale przekazywali je także inni hierarchowie ormiańscy, na przykład Kajetan Warteresiewicz i Grzegorz Romaszkan. „Wśród donatorów - pisze badaczka - odnajdujemy imiona dawnych seminarzystów, Ormian polskich, którzy pobierali naukę w szkole przy kongregacji w Wiedniu" "74. Rękopisy, o których wspomina Piruz Mnacakanian, dotyczą czasów staropolskich. Dzięki zachowanym znakom proweniencyjnym (lub innym źródłom wskazującym na ich polski rodowód) mogą one być przydatne do badań nad kontaktami duchownych z Galicji z wiedeńskim klasztorem mechitarystów i ich ośrodkiem studiów armenistycznych.

W bibliotece mechitarystów - prowadzonych obecnie przez o. Simona Bayana - poszukiwałem związków księży Sadoka i Dominika Barączów z tym zgromadzeniem. Jak się okazało, znany dziewiętnastowieczny dominikanin i historyk Sadok Barącz, zajmujący się nie tylko dziejami swojego zakonu, ale także nacji

68 J. Dashian, Katalog der armenischen Handschriften in der Mechitaristen-Bibliothek zu Wien, Wien 1895.

${ }^{69}$ H. Oskian, Katalog der armenischen Handschriften in der Mechitaristen-Bibliothek zu Wien, Wien 1963.

${ }^{70} \mathrm{H}$. Buschhausen, H. Buschhausen, Die illuminierten armenischen Handschriften der Mechitharisten- Congregation in Wien, Wien 1976.

71 N. Akinian, Katalog der armenischen Handschriften der Bibliotheken zu Lwow und Stanislawow, Wien 1961.

72 P. Mnacakanian, Sprawozdanie z poszukiwań polono-armeniców w Wiedniu. Krótki zarys historii Kongregacji Mechitarzystów w Wiedniu, „Biuletyn Ormiańskiego Towarzystwa Kulturalnego", 2011, 66/67, s. 65-80.

${ }^{73}$ Idem, Kultura języka ormiańskiego w dawnej Polsce, Kraków 2015, mszps rozprawy doktorskiej, Archiwum Uniwersytetu Jagiellońskiego w Krakowie, s. 214-226. Zob. także recenzję tej rozprawy: A. A. Zi įba, O pożytkach ze studiowania dziet kultury w dawnej Polsce, spisanych w języku ormiańskim, czyli o dysertacji dr Piruzy Mnacakanian, „Biuletyn Ormiańskiego Towarzystwa Kulturalnego", 2016, 84/85, s. 36-43.

${ }^{74}$ P. Mnacakanian, Kultura języka ormiańskiego, s. 55. Zob. także J. Rydzkowska-Kozak, Historia polskich zbiorów rękopisów ormiańskich, w: Stan badań nad wielokulturowym dziedzictwem dawnej Rzeczypospolitej, 4, red. W. Walczak, K. Łopatecki, Białystok 2013, s. 17-39, zwłaszcza s. 26 i 34-35. 
ormiańskiej, z której się wywodził ${ }^{75}$, raczej nie miał takich kontaktów. Inaczej rzecz się miała z proboszczem parafii ormiańskokatolickiej w Łyścu, a następnie kanonikiem lwowskim - wspomnianym już Dominikiem Barączem ${ }^{76}$, który miał je od lat młodzieńczych. Do tej pory ten wątek jego życia raczej nie był znany. I tak w 1819 roku rozpoczął on naukę w gimnazjum prowadzonym przez wiedeński klasztor, w 1823 roku złożył w nim śluby zakonne, jednak już w 1824 roku opuścił Wiedeń i wstąpił do seminarium duchownego we Lwowie, w którym przygotowywał się do przyjęcia święceń kapłańskich. Resztę życia związał z ormiańskokatolicką archidiecezją lwowską ${ }^{77}$. Informacje o jego „mechitarystycznym" okresie dostarcza księga profesji wiedeńskiego klasztoru, przechowywana w jego bibliotece ${ }^{78}$. Mari Kristin Arat, w opracowaniu poświęconym wiedeńskim mechitarystom, wspomina go jako czternastoletniego ucznia szkoły klasztornej, a przy tej okazji snuje znamienne refleksje. Podkreśla, że szkoła miała być przeznaczona dla ormiańskich chłopców z Bliskiego Wschodu i zastanawia się, jak ktoś urodzony w Galicji mógł się w niej znaleźć, czy można go w ogóle uznać za Ormianina, skoro nie urodził się na Wschodzie, a może - przypuszcza - u mechitarystów nie znalazł się dobrowolnie? ${ }^{79}$

Wspomniana księga profesji zawiera znacznie więcej nazwisk Ormian wywodzących się z Galicji i Bukowiny (teren archidiecezji lwowskiej obrządku ormiańskiego), którzy wstąpili do tego zgromadzenia. Był wśród nich Rafael Barącz (1847-1912) z Suczawy (na chrzcie otrzymał imię Józef), od 1857 roku aż do końca swojego życia mieszkaniec klasztoru wiedeńskiego, początkowo jako uczeń gimnazjum, a następnie zakonnik, wyświęcony na kapłana w 1867 roku. Miał on również epizod pracy duszpasterskiej w Galicji, a mianowicie w parafii ormiańskokatolickiej w Brzeżanach. W przyszłości warto byłoby to cenne źró-

75 Szerzej na jego temat zob.: M. Miławicki, „Świat ode mnie zawsze rzeczy nadzwyczajnych wymagat, a ponadto niestusznie”. O. Sadok Wincenty Baracz OP (1814-1892) w świetle źródet, „Lehahayer”, 2, 2013, s. 153-198.

76 Zdaniem ks. Tadeusza Isakowicza-Zaleskiego był on bliskim krewnym o. Sadoka Barącza. Ta kwestia wymaga jednak wyjaśnienia. Por. T. Zaleski, Słownik biograficzny duchownych ormiańskokatolickich, s. 34.

${ }^{77}$ Liczę, że w najbliższym czasie uda mi się przygotować jego rys biograficzny, tym bardziej że istnieje sporo ciekawych materiałów źródłowych na jego temat, nie tylko u mechitarystów wiedeńskich, także w zbiorach Fundacji Kultury i Dziedzictwa Ormian Polskich w Warszawie i Centralnego Państwowego Archiwum Historycznego Ukrainy we Lwowie.

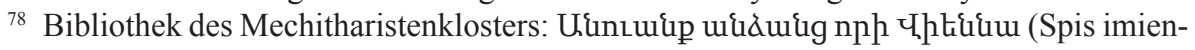
ny [mechitarystów] w Wiedniu), bez sygn. Księga ta w całości jest spisana w języku ormiańskim i prowadzona na bieżąco aż do naszych czasów. Wspomina ją P. Mnacakanian (Sprawozdanie z poszukiwań, s. 76-77), nazywając „rejestrem Kongregacji”.

${ }^{79}$ M. K. Arat, Die Wiener Mechitharisten, s. 44. Autorka, pisząc o Dominiku Barączu, nie powołuje się na zbiory biblioteki mechitarystów wiedeńskich, ale na archiwalia dotyczące tegoż klasztoru, a znajdujące się w Austriackim Archiwum Państwowym (ÖSA: AVA, Kultus, AK, Katholisch, 738.3, sygn. 92, Mechitaristen, k. 116b). 
dło, jakim jest księga profesji, poddać dalszej analizie w poszukiwaniu innych jeszcze mechitarystów lub ich uczniów z archidiecezji lwowskiej.

W zbiorach mechitarystów wiedeńskich znajdujemy także korespondencję nadchodzącą od polskich Ormian, głównie osób duchownych. Przykładowo można tu wymienić listy wspomnianego już Dominika Barącza, pisane zarówno w języku polskim, jak też ormiańskim i niemieckim. Kapłan ten świetnie władał językiem ormiańskim w słowie i piśmie. W najbliższym czasie chciałbym znalezione w Wiedniu jego listy przygotować do druku. Na razie brak odpowiedzi na pytanie, z kim konkretnie korespondował, czy była to jedna osoba, do której pisał w tych trzech językach, czy kilka. W listach tych zamieszcza sporo danych o swoich losach, o parafii w Łyścu oraz o duchownych i świeckich osobistościach ormiańskich z Galicji.

Zachowała się także teczka o. Rafaela Barącza. Znajduje się w niej nominacja na administratora parafii ormiańskokatolickiej w Brzeżanach, wystawiona 8 maja 1877 roku przez arcybiskupa Romaszkana, oraz teksty kazań głoszonych w Galicji. Wiadomo, że w bibliotece mechitarystów wiedeńskich są też materiały dotyczące innych galicyjskich duchownych ormiańskich, na przykład korespondencja arcybiskupa Józefa Teodorowicza ${ }^{80}$, oraz teczki personalne mechitarystów: Piotra Mojzesowicza, Bartłomieja Kosteckiego, Antoniego Jakuba Kosińskiego i Szczepana Aristagesa Wojsterowicza, którzy w okresie galicyjskim pracowali duszpastersko w archidiecezji lwowskiej.

Niniejsza prezentacja archiwaliów dotyczących dziejów Kościoła i duchowieństwa ormiańskokatolickiego w Galicji nie wyczerpuje wszystkich źródeł, które można znaleźć w archiwach i bibliotekach Wiednia. Pozostają jeszcze do rozpoznania działy rękopisów Austriackiej Biblioteki Narodowej (Österreichische Nationalbibliothek) i Biblioteki Uniwersyteckiej (Universitätsbibliothek Wien). Nie jest wykluczone, że i tam mogą się znajdować materiały odnoszące się do galicyjskich Ormian. Mam jednak nadzieję, że to skromne i miejscami pewnie zbyt lakoniczne sprawozdanie da obraz potencjalnej bazy źródłowej, którą historyk zainteresowany ormiańskim wątkiem dziejów Galicji powinien uwzględnić w badaniach. Ufam również, że artykuł ten wpisuje się w cały już szereg tego typu przeglądów źródeł, jak chociażby te autorstwa Józefa Wołczańskiego, Franciszka Wasyla czy Tomasza Krzyżowskiego, którzy zajmowali się zasobami archiwalnymi do dziejów Kościoła ormiańskokatolickiego w Galicji (i szerzej na ziemiach polskich), przechowywanymi w repozytoriach lwowskich ${ }^{81}$. Podobne

${ }^{80} \mathrm{O}$ jego kontaktach z mechitarystami wiedeńskimi i weneckimi zob. T. Krzyżowski, Kontakty abpa Józefa Teodorowicza z hierarchia Kościoła ormiańskokatolickiego, „Biuletyn Ormiańskiego Towarzystwa Kulturalnego", 2018, 94/94, s. 73-77.

81 J. Wołczański, Inwentarz archiwum kurii archidiecezji ormiańskokatolickiej we Lwowie za lata 1616-1939, „Archiwa, Biblioteki i Muzea Kościelne”, 90, 2008, s. 233-285; F. Was yl, Przeszłość Kościoła ormiańskokatolickiego w zbiorach Centralnego Państwowego 
próby rekonesansu źródłowego odnośnie do tematyki ormiańskiej przeprowadza się też w książnicach polskich ${ }^{82}$. I chociaż wiele źródeł jest jeszcze nierozpoznanych, głównie z powodu ich rozproszenia, to dzięki takim kwerendom mamy coraz szerszy ogląd możliwości poznawczych w zakresie dziejów Ormian polskich.

\section{Bibliografia}

\section{Źródla archiwalne:}

Archiwum Fundacji Kultury i Dziedzictwa Ormian Polskich w Warszawie: Dokumenty aktowe, $\mathrm{nr} 7$

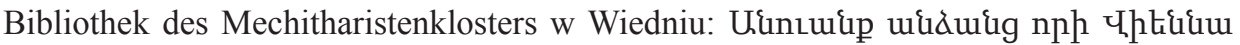
(Spis imienny [mechitarystów] w Wiedniu), bez sygn.

Österreichisches Staatsarchiv w Wiedniu:

Ogólne Archiwum Administracji (Allgemeines Verwaltungsarchiv), Kultus und Unterricht, Alter Kultus, Katholisch, 92, 216.3, 217.1, 217.2, 217.3, 217.4, 217.5, 520.1, 738.3, 930.9; Kultus und Unterricht, Neuer Kultus, Kath Akten, 79.12, 608.3, 640.2; Unterricht, Studienhofkommission, Teil 1, 103.3

Archiwum Domu, Dworu i Państwa (Haus-, Hof- und Staatsarchiv), Staatskanzlei, Provinzen Galizien, 3.2, 3.3; Staatskanzlei, FA Taaffe, 39-39; Diplomatie und Außenpolitik 1848-1918, Gesandtschafts- und Konsulatsarchive, Rom Geistliche Agentie Akten, 27.1, 31.1, 67.1, 84.1, 85.1, 154-1, 158.1, 159.1, 160.1, 205.1; Kabinettsarchiv, Kaiser-Franz-Akten, 218-5

\section{Źródła drukowane:}

Catalogus universi venerabilis cleri saecularis et regularis Archidioecesos Leopolitanae pro anno Domini MDCCCXXXIII, [Leopoli 1832 lub 1833]

Hierarchia catholica medii et recentioris aevi, sive Summorum pontificum - S. R. E. cardinalium ecclesiarum antistitum series e documentis tabularii praesertim Vaticani collecta, digesta, edita, 7, A pontificatu Pii PP. VII (1800) usque ad pontificatum Gregorii PP. XVI (1846), wyd. R. Ritzler, P. Sefrin, Patavii 1968

Rosco Bogdanowicz M., Wspomnienia, wstęp A. Knot, oprac. J. Gintel, 1, Kraków 1959

\section{Opracowania:}

Akinian N., Katalog der armenischen Handschriften der Bibliotheken zu Lwow und Stanislawow, Wien 1961

Historycznego Archiwum Ukrainy we Lwowie, „Prace Historyczno-Archiwalne”, 16, 2005, s. 233-243; T. Krzyżow ski, Źródła archiwalne do dziejów Kościoła ormiańskokatolickiego we współczesnych zbiorach lwowskich archiwów, bibliotek i muzeów, „Lehahayer”, 3, 2015, s. 95-114. Zob. także uwagi A. Krochmal, Archiwa lwowskie jako źródło do badań stosunków narodowościowych $i$ wyznaniowych $w$ Rzeczypospolitej w 2. pot. XVIII w., w: Stan badań nad wielokulturowym dziedzictwem dawnej Rzeczypospolitej, 6, red. W. Walczak, K. Łopatecki, Białystok 2013, s. 95-111.

${ }^{82}$ Zob. np. K. Rzemieniecki, Rękopisy zwiąane z historia i kultura Ormian w zbiorach Działu Rękopisów w Bibliotece Zakładu Narodowego im. Ossolińskich, „Lehahayer”, 2, 2013, s. 199-217. 
Arat M. K., Die Wiener Mechitharisten. Armenische Mönche in der Diaspora, WienKöln 1990

Badzik S. K., Mekhitarist Congregation in Vienna. A Historical Survey, Vienna 1991

Barącz S., Rys dziejów ormiańskich, Tarnopol 1869

Bihl W., Die Armenischen Kirchen, w: Die Habsburgermonarchie 1848-1918, 4, Die Konfessionen, red. A. Wandruszka, P. Urbanitsch, Wien 1985

Blažejovskyj D., I teatini e i Pontifici Collegi Armeno e Ucraino di Leopoli (1665-1784), „Regnum Dei”, 35, 1979, 105, s. 205-248

Blažejovskyj D., Ukrainian and Armenian Pontifical Seminaries of Lviv (1665-1784), Rome 1975

Buschhausen H., Buschhausen H., Die illuminierten armenischen Handschriften der Mechitharisten- Congregation in Wien, Wien 1976

Chlebowczyk J., Polonica $w$ archiwach wiedeńskich, „Kwartalnik Historyczny”, 65, 1958, 1, s. 332-335

Chotkowski W., Historya polityczna dawnych klasztorów panieńskich w Galicyi 17731848 na podstawie akt Cesarskiej Kancelaryi Nadwornej, Kraków 1905

Chotkowski W., Historya polityczna Kościoła w Galicyi za rząów Marii Teresy, 2, Kraków 1909

Chotkowski W., Ze studyów $w$ archiwum ministerstwa wyznań $i$ oświaty $w$ Wiedniu do historyi klasztorów w Galicyi, „Sprawozdanie z Czynności i Posiedzeń Akademii Umiejętności w Krakowie", 4, 1899, 9, s. 6-9 (przedruk w: idem, Kasaty klasztorów w Galicji. Wybór prac, wstęp i wyd. A. Gąsior, J. Królikowski, Kraków 2019, Dziedzictwo Kulturowe po Skasowanych Klasztorach, 10, s. 17-20)

Ciara S., C. K. Ministerstwo Wyznań i Oświaty (K. k. Ministerium für Kultus und Unterricht), w: Archiwum Główne Akt Dawnych w Warszawie. Przewodnik po zasobie, 2, Epoka porozbiorowa, Warszawa 1998, s. 653-658

Ciara S., Kwerenda w archiwach wiedeńskich, „Archeion”, 95, 1995, s. 248-253

Dashian J., Katalog der armenischen Handschriften in der Mechitaristen-Bibliothek zu Wien, Wien 1895

Engel-Jánosi F., Die politische Korrespondenz der Päpste mit den österreichischen Kaisern 1804-1918, Wien-München 1964, Veröffentlichungen zur Kirchengeschichte Österreichs, 2

Engel-Jánosi F., Österreich und der Vatikan 1846-1918, 1-2, Graz-Wien-Köln 1958-1960

Engelbrecht H., Geschichte des österreichischen Bildungswesens. Erziehung und Unterricht auf dem Boden Österreichs, 3, Von der frühen Aufklärung bis zum Vormärz, Wien 1984

Gaul J., Polonika w Allgemeines Verwaltungsarchiv w Wiedniu, „Archeion”, 101, 2000, s. 115-128

Gaul J., Polonika $w$ archiwach austriackich, „Archeion”, 110, 2007/2008, s. 118-144

Gaul J., Polonika w Archiwum Parlamentu w Wiedniu. Archiwum Izby Posłów Rady Państwa 1861-1918, Warszawa 2014

Gaul J., Polonika w zespole „, Urząd Nadzoru Wojennego” w Archiwum Wojny w Wiedniu, „Miscellanea Historico-Archivistica”, 24, 2017, s. 311-323

Goldinger W., Die Zentralverwaltung in Cisleithanien - Die zivile gemeinsame Zentralverwaltung, w: Die Habsburgermonarchie 1848-1918, 2, Verwaltung und Rechtswesen, red. A. Wandruszka, P. Urbanitsch, Wien 1975, s. 125-128 
Gross L., Reichsarchive, w: Inventare Österreichischer Staatlicher Archive, 5, Inventare des Wiener Haus-, Hof- und Staatsarchivs; 4, Gesamtinventar des Wiener Haus-, Hofund Staatsarchiv. Aufgebaut auf der Geschichte des Archivs und seiner Bestände, red. L. Bittner, Wien 1936

Hernitt R. H., Ministerium für Kultus und Unterricht, w: Österreichisches Staatswörterbuch, 3, red. E. Mischler, J. Ulbrich, Wien 1907, s. 625-630

Höslinger R., Das Kultuswesen in der Zeit von 1867-1948, w: 100 Jahre Unterrichtsministerium 1848-1948. Festchrift des Bundesministeriums für Unterricht in Wien, red. E. Loebenstein, Wien 1948, s. 427-233

Inglisian W., Die armenischen Wiener Mechitharisten, Wien 1955

Kowalczyk J., Gmach kolegium Teatynów we Lwowie i jego twórcy - Salvi i Chiaveri, w: Sztuka Kresów Wschodnich, 5, red. A. Betlej, P. Krasny, Kraków 2003, s. 53-64

Krajewska H., Polen - Österreich vom 16. bis zum 20. Jahrhundert. Ein Dokumentenführer, Warszawa 1995

Krętosz J., Archidiecezja lwowska obrządku łacińskiego w okresie józefinizmu (17721815), Katowice 1996

Krochmal A., Archiwa lwowskie jako źródło do badań stosunków narodowościowych $i$ wyznaniowych $w$ Rzeczypospolitej w 2. pot. XVIII w., w: Stan badań nad wielokulturowym dziedzictwem dawnej Rzeczypospolitej, 6, red. W. Walczak, K. Łopatecki, Białystok 2013, s. 95-111

Krzyżowski T., Archidiecezja lwowska obrzadku ormiańskokatolickiego w latach 19021938, Kraków 2018, mszps rozprawy doktorskiej, Uniwersytet Papieski Jana Pawła II w Krakowie

Krzyżowski T., Kontakty abpa Józefa Teodorowicza z hierarchia Kościoła ormiańskokatolickiego, „Biuletyn Ormiańskiego Towarzystwa Kulturalnego”, 2018, 94/94, s. $73-77$

Krzyżowski T., Źródła archiwalne do dziejów Kościoła ormiańskokatolickiego we wspótczesnych zbiorach lwowskich archiwów, bibliotek i muzeów, „Lehahayer”, 3, 2015, s. 95-114

Kumor B., Kwerenda naukowa w Haus-, Hof- und Staatsarchiv oraz w Allgemeines Verwaltungsarchiv $w$ Wiedniu w latach 1966-1971, „Summarium”, 3, 1974, 112-115

Kumor B., Obsada arcybiskupstwa ormiańskokatolickiego we Lwowie w latach niewoli narodowej (1772-1918), „Analecta Cracoviensia”, 26, 1994, s. 371-384

Kumor B., Obsada biskupstwa krakowskiego w latach 1790-1914, „Analecta Cracoviensia", 8, 1976, s. 321-343, https://doi.org/10.15633/acr.2966

Kumor B., Obsada biskupstwa tarnowskiego w latach 1783-1807, „Analecta Cracoviensia", 13, 1981, s. 425-441, https://doi.org/10.15633/acr.2815

Kumor B., Obsada metropolii lwowskiej obrzadku łacińskiego w latach 1772-1918, „Analecta Cracoviensia”, 9, 1977, s. 447-468, https://doi.org/10.15633/acr.2972

Kumor B., Obsada metropolii lwowskiej obrzadku łacińskiego w latach 1780-1850, „Folia Societatis Scientiarum Lublinensis. Humanistyka”, 18, 1976, 2, s. 95-105

Kumor B., Ustrój i organizacja Kościoła polskiego w okresie niewoli narodowej 17721918, Kraków 1980

Kumor B., Ważniejsze polonika kościelne $w$ archiwach państwowych $w$ Wiedniu, „Archiwa, Biblioteki i Muzea Kościelne”, 37, 1978, s. 307-311

Kuster T., Die italienreise Kaiser Franz'I von Österreich 1819, „Römische Historische Mitteilungen", 46, 2004, https://doi.org/10.1553/RHM46s305 
Maleczyński K., Turoń B., Średniowieczne silesiaca i polonica w zbiorach bibliotecznych $i$ archiwalnych $w$ Wiedniu, „Śląski Kwartalnik Historyczny Sobótka”, 18, 1963, 1, s. 84-93

Mark R. A., Galizien unter österreichischer Herrschaft. Verwaltung - Kirche - Bevölkerung, Marburg 1994, Historische und Landeskundliche Ostmitteleuropa - Studien, 13

Mester R., Österreichs Unterrichtsverwaltung und Unterrichtsanstalten 1760-1960, w: 200 Jahre Österreichische Unterrichtsverwaltung 1760-1960. Festschrift des Bundesministeriums für Unterricht in Wien, red. A. Kolbabek, Wien 1960, s. 67-98

Mikrut J., Bischöfe aus Galizien berichten an Kaiser Franz I. Ein Beitrag zur Geschichte der Katholischen Kirche in der Habsburgermonarchie, Wien 1995

Mikrut J., Die galizische Diözese Tyniec-Tarnów in den Visitationsberichten von Bischof Thomas Gregorius Ziegler (1822-1827), Wien 2009

Miławicki M., ,Świat ode mnie zawsze rzeczy nadzwyczajnych wymagat, a ponadto niestusznie”. O. Sadok Wincenty Barącz OP (1814-1892) w świetle źródet, „Lehahayer”, 2, 2013, s. 153-198

Mnacakanian P., Kultura języka ormiańskiego w dawnej Polsce, Kraków 2015, mszps rozprawy doktorskiej, Archiwum Uniwersytetu Jagiellońskiego w Krakowie

Mnacakanian P., Sprawozdanie z poszukiwań polono-armeniców w Wiedniu. Krótki zarys historii Kongregacji Mechitarzystów w Wiedniu, „Biuletyn Ormiańskiego Towarzystwa Kulturalnego", 2011, 66/67, s. 65-80

Murray R., The Armenian Mekhitarist Monastery in Vienna, „Eastern Churches Quarterly", 11, 1956, s. 279-282

Musil J., Zur Geschichte des österreichischen Unterrichtsministeriums 1848-1948, w: 100 Jahre Unterrichtsministerium 1848-1948. Festchrift des Bundesministeriums für Unterricht in Wien, red. E. Loebenstein, Wien 1948, s. 7-36

Nabywaniec S., Ecclesiastica galicyjskie $w$ zbiorach Allgemeines Verwaltungsarchiv w Wiedniu, „Prace Historyczno-Archiwalne”, 13, 2003, s. 199-206

Obertyński Z., Kościół ormiański w zaborze austriackim, w: Historia Kościoła w Polsce, 2/1, red. B. Kumor, Z. Obertyński, Poznań 1979, s. 651-656

Oskian H., Katalog der armenischen Handschriften in der Mechitaristen-Bibliothek zu Wien, Wien 1963

Petrowicz G., La Chiesa armena in Polonia e nei paesi limitrofi, 3, Roma 1988, Studia Ecclesiastica, 17, Historica, 10

Ploch G., Zespót nr 102, „Klöster und Stifte: Galizien”, w Allgemeines Verwaltungsarchiv oraz wybrane inne archiwalia dotyczace klasztorów i zakonów w Galicji w zbiorach Österreichisches Staatsarchiv, w: Kasaty klasztorów na obszarze dawnej Rzeczypospolitej Obojga Narodów i na Śląsku na tle procesów sekularyzacyjnych w Europie, 3, red. M. Derwich, Wrocław 2014, s. 17-45

Pobóg-Lenartowicz A., Źródła do dziejów klasztorów śląskich przechowywane w Austriackim Archiwum Państwowym w Wiedniu (Österrichisches Staatsarchiv), ,Śląski Kwartalnik Historyczny Sobótka", 66, 2011, 4, s. 93-97

Polonika w Austriackim Archiwum Państwowym 1772-1918, oprac. J. Gaul, Warszawa 2003

Prokop K. R., Wypisy z XVIII- i XIX-wiecznej prasy periodycznej na temat sakr biskupich Kościoła katolickiego z historycznych ziem polskich, „Biuletyn Biblioteki Jagiellońskiej”, 62, 2012, s. 21-65 
R[ozwadowski] B., Obertyn, w: Stownik geograficzny Królestwa Polskiego i innych krajów stowiańskich, 7, red. B. Chlebowski, W. Walewski, Warszawa 1886, s. 323

Röskau-Rydel I., Kultur an der Peripherie des Habsburger Reiches. Die Geschichte des Bildungswesens und der kulturellen Einrichtungen in Lemberg von 1772 bis 1848, Wiesbaden 1993, Studien der Forschungsstelle Ostmitteleuropa an der Universität Dortmund, 15

Rydzkowska-Kozak J., Historia polskich zbiorów rękopisów ormiańskich, w: Stan badań nad wielokulturowym dziedzictwem dawnej Rzeczypospolitej, 4, red. W. Walczak, K. Łopatecki, Białystok 2013, s. 17-39

Rzemieniecki K., Rękopisy związane z historia i kultura Ormian w zbiorach Dziatu Rękopisów w Bibliotece Zakładu Narodowego im. Ossolińskich, „Lehahayer”, 2, 2013, s. $199-217$

Saurer E., Die politischen Aspekte der österreichischen Bischofsernennungen 1867-1903, Wien-München 1968, Veröffentlichungen zur Kirchengeschichte Österreichs, 6

Scarabelli G., I teatini a Leopoli, „Regnum Dei”, 59, 2003, 129, s. 211-223

Spreitzer H., Das österreichische Unterrichtsministerium 1848-1960, „Österreich in Geschichte und Literatur", 4, 1960, s. 8-14

Stropp R., Die Ankten des k. u. k. Ministeriums des Äußern 1848-1918, „Mitteilungen des Österreichischen Staatsarchivs", 20, 1967, s. 389-506; 30, 1977, s. 398-444; 32, 1979, s. 306-349; 33, 1980, s. 357-415; 34, 1981, s. 411-456

Tyszkowski K., Polonica w zbiorach Archiwum Państwowego w Wiedniu (sprawozdanie z poszukiwań archiwalnych głównie dla czasów Zygmunta III), „Archeion”, 5, 1929, s. $70-88$

Walter F., Die zentrale Schulverwaltung in Österreich 1760-1848, „Österreich in Geschichte und Politik", 4, 1960

Wasyl F., Ormianie w przedautonomicznej Galicji. Studium demograficzno-historyczne, Kraków 2015, Studia Galicyjskie, 4

Wasyl F., Przeszłość Kościoła ormiańskokatolickiego w zbiorach Centralnego Państwowego Historycznego Archiwum Ukrainy we Lwowie, „Prace Historyczno-Archiwalne", 16, 2005, s. 233-243

Weinzierl E., Das Haus-, Hof- und Staatsarchiv und die Geschichtswissenchaft 18481967, „Mitteilungen des Österreichischen Staatsarchivs”, 16, 1963, s. 250-260

Woliński J., Wójcik Z., Źródła do historii Polski w Haus-, Hof-und Staatsarchiv w Wiedniu, „Archeion”, 28, 1958, s. 131-157

Wołczański J., Inwentarz archiwum kurii archidiecezji ormiańskokatolickiej we Lwowie za lata 1616-1939, „Archiwa, Biblioteki i Muzea Kościelne”, 90, 2008, s. 233-285

Zaleski T., Słownik biograficzny duchownych ormiańskokatolickich oraz duchownych rzymskokatolickich pochodzneia ormiańskiego w Polsce w latach 1750-2000, Kraków 2001

Zięba A. A., O pożytkach ze studiowania dziet kultury w dawnej Polsce, spisanych w języku ormiańskim, czyli o dysertacji dr Piruzy Mnacakanian, „Biuletyn Ormiańskiego Towarzystwa Kulturalnego", 2016, 84/85, s. 36-43

\section{Netografia:}

https://www.archivinformationssystem.at/detail.aspx?ID=710 


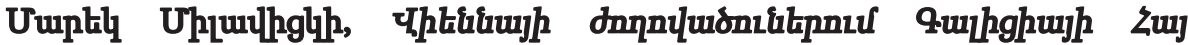

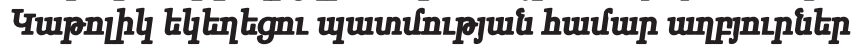

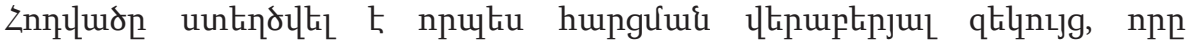

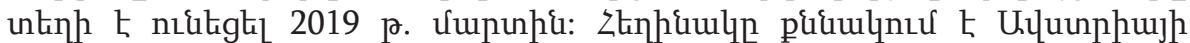

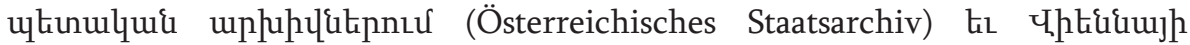
Uhuppunjui uhupuinıpjui qpunupuinnu (Bibliothek des Mechitharis-

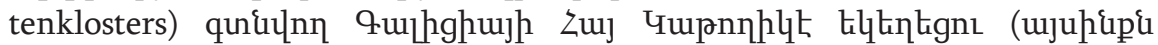

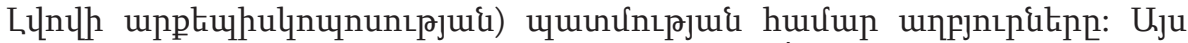

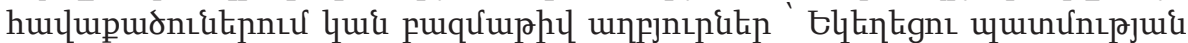

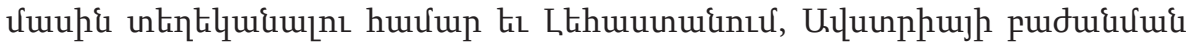

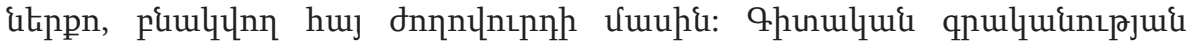

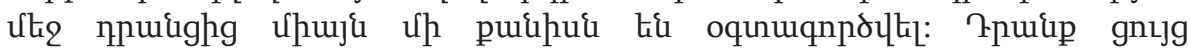

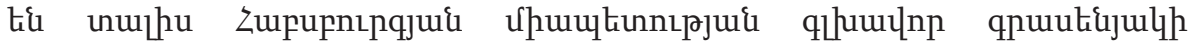

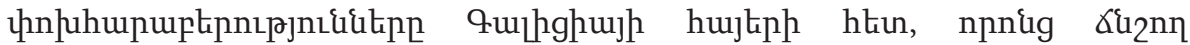

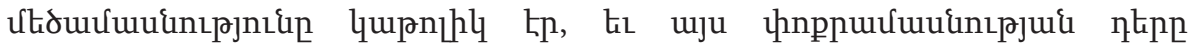

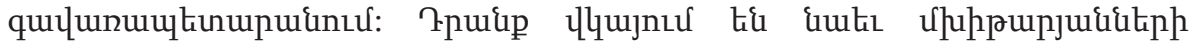

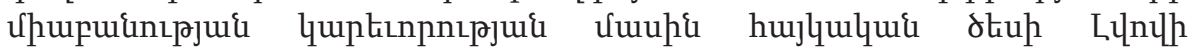

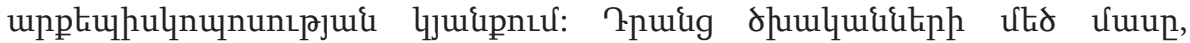

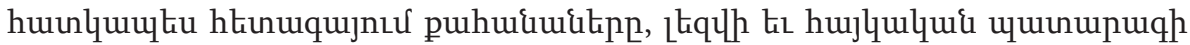

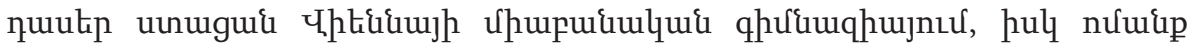

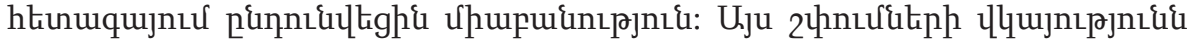

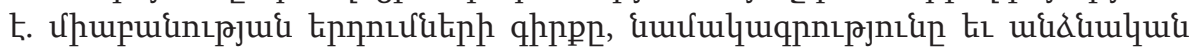

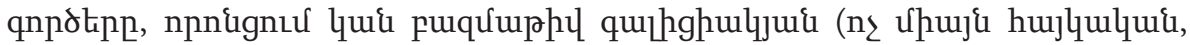

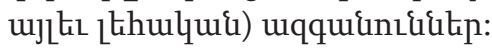

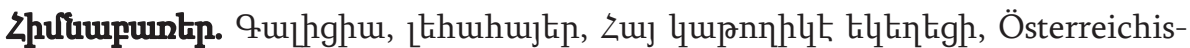
ches Staatsarchiv, Bibliothek des Mechitharistenklosters; Tnuhipl fupni々,

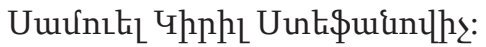

\section{Marek Miławicki O.P., Sources for the History of the Armenian Catholic Church in Galicia in the Viennese Collections}

The article is a report from a query that took place in March 2019. The author discusses sources that relate to the history of the Armenian Catholic Church in Galicia (i.e. the Archdiocese of Lwów, Lemberg) found in the Austrian State Archives (Österreichisches Staatsarchiv) and in the Library of the Mechitharist Congregation (Bibliothek des Mechitharistenklosters) in Vienna. The collections contain a wealth of sources on the history of the Church and the Armenians living in Poland on the territories acquired in 1772 by the Austrian Empire, and until now only some of them have been used in the scientific literature. They present the relations of the central offices of the Habsburg monarchy with the Galician Armenians (who, in the overwhelming majority, were Catholics), and the role of this minority in the provincial administration. The sources also denote the importance of the religious 
congregation of Mechitarists in the life of the Armenian Catholic Archdiocese of Lwów. Many future priests learnt the Armenian language and Armenian liturgy at the Viennese religious secondary school (gymnasium) led by Mechitarists, and later a number of them joined the congregation. The book of religious professions, the letters and personal files, which mention a great number of Galician names, not only of Armenian descent (like archbishop Samuel Cyryl Stefanowicz or Rev. Dominik Barącz), but also of Polish origin serve as evidence of the aforementioned bond.

Keywords: Galicia, Polish Armenians, Armenian Catholic Church, Österreichisches Staatsarchiv, Bibliothek des Mechitharistenklosters; Dominik Barącz, Samuel Cyryl Stefanowicz 